\title{
The relationship of Turnover intention with job satisfaction, job performance, Leader member exchange, Emotional intelligence and organizational commitment
}

Iqra Saeed

Department of Management Sciences, The Islamia University of Bahawalpur, Pakistan

Momina Waseem

Department of Management Sciences, The Islamia University of Bahawalpur, Pakistan

Sidra Sikander

Department of Management Sciences, The Islamia University of Bahawalpur, Pakistan

\author{
Muhammad Rizwan \\ Lecturer, Department of Management Sciences \\ The Islamia University of Bahawalpur, Pakistan \\ E-mail: rizwan.arshad@iub.edu.pk
}

DOI:10.5296/ ijld.v4i2.6100 URL: http://dx.doi.org/10.5296/ ijld.v4i2.6100

\begin{abstract}
Turnover is a painful issue in the organizations, in the world of tough competition the organizations try to minimize their turnover ratio and save their cost, turnover cost consists of hiring, recruiting and selecting the employees. The purpose of current study to is to know the effect of some of the factors which affect the turnover intention of employees. We find the impact of organizational commitment, emotional intelligence, leader membership exchange, job performance and job satisfaction on turnover intention. We conducted a survey and took a sample of 200 employees. We used questionnaire method to collect information from the respondents. By using linear regression analysis method we found that Job satisfaction, job performance and leader membership exchange has a direct negative influence on the turnover intention. The results provide understanding that how these variables affect the turnover intention and how to reduce turnover rate.
\end{abstract}

Keywords: Turnover, satisfaction, job performance 


\section{Introduction}

Turnover intention is a serious issue especially today in which employee leaves the organization or organization fired them. Turnover intention is the organization's employees plan to leave their jobs or to fire the employees. Turnover intention can be either voluntary or involuntary. In voluntary turnover, employee leaves the organization willingly. It occurs when the employee have an alternative best opportunity. While involuntary turnover intention occurs when organization isn't satisfied with an employee performance and makes decision to fire him. The general purpose of this research is to study the turnover intention of employees and the specific purpose is to identify the effect of Organizational commitment, Job performance, Emotional Intelligence, Leader member exchange (LMX) and Job satisfaction on turnover intention of employees.

The current study shows the effects of these five variables on turnover intention; Job satisfaction, Organizational commitment, leader membership exchange (LMX), Emotional intelligence, Job performance. Job satisfaction is the feeling of getting achievement which you practice in the job. Job satisfaction has a negative impact on turnover intention. High job satisfaction is associated with low turnover intention and low job satisfaction leads toward high turnover intention. It is the best indicator of employ intention to perform.

Emotional intelligence (EI) is termed as the ability to find, assess, and control the emotions of oneself, of others, and of groups. Emotions are very useful to gather information that helps one to discover and understand social environment. Emotional intelligence makes the relationships strong in the workplace. It has direct negative impact on turnover intention. The more the person will be emotionally intelligent lower will be the turnover intention.

Leader-Member Exchange describes the ability of a leader in groups to maintain his position through a series of tacit exchange agreements and dealings with their members. The leader-member exchange theory of leadership focuses on the two-way relationship (dyadic relationships) between supervisors and subordinates.LMX has negative impact on turnover intention. If the exchange of information between leader and follower will be more the lower will be the turnover intention.

Organizational commitment is an attachment with the organization and a positive response to working conditions (Mathieu and Zajac, 1990). It has a negative impact on turnover intentions. Employees who have strong relation with the organization have less intention to move toward another organization than the employees who are not effectively and strongly committed.

Job performance is the skill of an employee to do various jobs, related to job necessities. Job performance and turnover intention are directly related to each other and show significant negative relation. High job performance encourages the employees and leads toward reward, so turnover intention decreases while negative job performance indicates that employ is not enough efficient to gain benefits and leads to leave the organization. 


\section{Literature review}

\section{Turnover intention}

Every organization faces turnover of employees, some of them leaves the organization voluntarily while the organizations discharge some of their employees from the organization. All kind of turnover incurs cost of replacement of those separators, recruitment, selection etc. Studying the behavior of employees who quit their organization is turnover analysis of employees. The organizations can reduce turnover rate but they cannot reduce it to $0 \%$, high turnover rates are not good for the organization so, the organizations try to retain their employees and save their cost.

When the employees are not satisfied with their jobs and organizations do have not trust in their employees the employee's intention towards turn over will be greater, they will leave the organization and the duration of their job will be smaller (Jeffrey, 2007). Turnover is of two types voluntary turnover and involuntary turnover, when employer fire the employees it is said to be involuntary turnover and when the employees quit their job by their willingness it is called involuntary turnover.(Dess and shaw 2001). According to (Staw 1980) Turnover have both positive and negative effects on the organization. The organization has to pay a heavy cost of replacement of employees as a negative consequence; the organization has to pay a big portion of its time to recruiting and selecting activities which will increase the administration's responsibilities.

According to (riley, 2006) Employees worker interdependently in an organization, quitting of some of the employees Effect the efficiency of the remaining employees. It is good for the organization to fire The employees who are not productive and replace them with the productive one's which will increase the human capital and the new one's will bring innovative ideas and solutions. According to (Grobler et al, 2005) to reduce conflicts and bring change and innovation to the organization minor turnover is healthy for $t$ he organization.

\section{Job satisfaction}

When your work is having worth you will be happy and satisfied with your performance this I job satisfaction. According to (Spector, 1997) Job satisfaction is work related research topic in the field of organizational psychology, organizational behavior and in the industrial area. According to (Spector, 1997) there is an association between job satisfaction and turnover intention of employees. According to (Brayfield and Crockett, 1955; Vroom, 1964) job satisfaction has direct association with the turnover intention. According to Mobley (1977) Job satisfaction is negatively related with the turnover intention of employees. Employees often think to leave their job; they often make comparison of their current job with the others and evaluate the alternatives which they can get by leaving their recent job. According to (Susskind et al, 2000) job satisfaction has a significantly negative association with turnover intention on consistent basis. According to (Blau, 1987) researchers have proved that job satisfaction has direct influence over the turnover intention.

H1: Job satisfaction is negatively associated with turnover intention. 


\section{Job performance}

Job performance is the capability of worker to do various jobs due to his job requirements. Completion of job-related responsibilities by an employee shows his performance and it is linked with achievement or failure. Performance is measured by different factors including organizational skills, time management, leadership skills and efficiency to evaluate each employee individually and it is the cause of significant impact on turnover intention. The relation of turnover intention and job performance is evaluated by different researches (e.gBirnbaum and Somers, 1993; Jackofsky, 1984; Keller, 1984). Prior studies also showed a significant relation among turnover and performance. According to Expectancy theory which explains that the negativity of job performance means employee is not competent to gain benefits and it results to quitting (Vroom, 1964). Allen and Griffeth (1999) studied that if organization shows negative feedback against their better performance or they receive negative response then it leads to think of quitting or leave the organization.

According to Lee and Mitchell`s (1994), if employees work properly but they do not gain which they expect then they often think to leave the organization. We can say that if job performance is high, there are rewards for employees or it leads to increase in job satisfaction also so employees think to remain in organization for longer time but if they show negative performance then it leads to turnover intention.

H2: Job performance has a negative association with turnover intention.

\section{Leader member exchange (LMX)}

Leader member exchange provides the base to define the quality of a dyadic relationship between leader and members of his/her work group. Leader membership exchange theory focuses on interactions between the leaders and followers despite of other theories. Focal point of relationship process is the relation of leader and its followers. Strength of every relationship makes follower feel that they are the part of group which results in prevention from negative perceptions and inequities. Leadership making encourages partnerships building and helps in easy achievement of goals and accomplishment of process.

As the theory of LMX states a leader a leader may have different type of relationships with the members of groups or with different work groups. The members who maintain high quality relationships with their leaders mostly have superior handling in which may include authority of decision making (liden and graen 1980), comparatively higher opportunities to grow (graen and scandura 1987) and all time help and support (kraimer et al 2001). Analysis of this theory (gerstner and day 1997) validate that high quality of LMX makes the achievement of desirable work results very easy, improved performance ratings, higher level of job satisfaction, and organizational commitment, and decreased rate of employees intention to quit. The Relationship of turnover intention and LMX proposes that members who possess low quality of LMX they may have weak relationship with their leader so they 
may have greater turnover intention than those with higher quality of LMX (Bauer et al,2006: Gerstner and day, 1997: Schyns et al 2007).

H3: LMX has a direct negative association with turnover intention.

\section{Emotional Intelligence}

Emotional intelligence can be stated as the quality of a person to find, evaluate, and control the emotions of others, of oneself and of groups. Mayer and Salovey (1997) proposed a model of emotional intelligence that describes four inter-related emotion processing capabilities: the perception, understanding, assimilation, and management of own and others' emotions. The first agenda is based on the model of emotional intelligence of Mayer and Salovey (1997) that emphasizes emotional intelligence as being a concept that focuses on relationship between cognition and emotion .By considering the work place with respect to the emotional intelligence, Jordan et al. (2002), argues that there are certain practical qualities that are possessed by the people who are emotionally intelligent. By Using the model given by Mayer and Salovey (1997) it is proposed that effective employees are required to b especially attentive to their own emotions and emotions of others in that work area. They must be able to manage their own emotions and the emotions of others. Four dimensions of definition were proposed by Jordan and Lawrence that replicated the highly accurate model of Mayer and Salovey (1997) known as model of emotional intelligence. This model comprises four constructs:

(1) Awareness of own emotion

(2) Management of own emotion

(3) Awareness of others' emotion

(4) Management of others' emotions

H4: Emotional intelligence has direct negative association with turnover intention.

\section{Organizational commitment}

Organizational commitment is described as the employee association with the organization or the collection of feelings and beliefs about the organization as to involve or attach emotionally in a organization.

Organizational commitment is an attachment with organization (Mathieu and Zajac, 1990). Organizational commitment means a positive response toward working conditions and has a strong believe on organization goals and wish to attain effective relation with organization (Scholarios and Marks, 2004).Organizational commitment and turnover intention are significantly related to each other and have a negative association (Al Arkoubi et al. 2007). 


\section{Macrothink}

International Journal of Learning \& Development

ISSN 2164-4063

2014, Vol. 4, No. 2

When commitment is valued by organization and employees receive positive response and encouragement then it works as motivation and to remain in the organization and to work for organization (Meyer and Allen ,1991)

Previous studies show a great effect on turnover intention due to organizational commitment and there is a negative relation between them (Lin and Chen, 2004a; Susskind et al., 2000; Van Breukelen et al., 2004). If employee commitment with organization is high and employees are fully involved to achieve the goals then they are motivated and keep their entity in the organization (Joiner et al., 2004; Near, 1989).

If commitment with organization is low and employees have no special interest toward organizational goals then they are discouraged and fired or may leave the organization.

H5: Organizational commitment has a negative association with turnover intentions.

\section{Model}

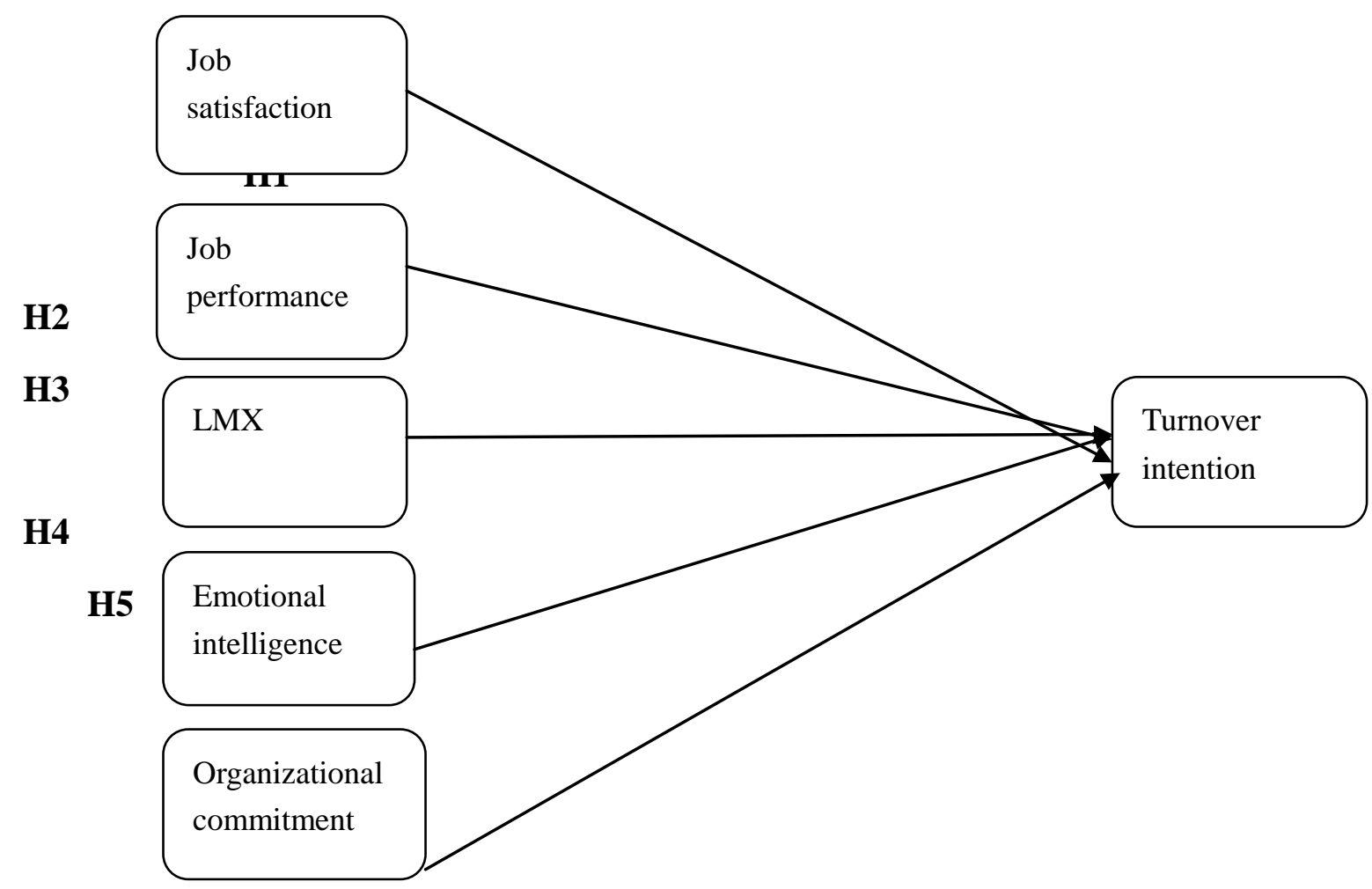

\section{Research methodology}

According to (Cress well, 1994 ) descriptive research means to demonstrate the current situation instead of making judgment and interpretation. The purpose of using quantitative research is to check the hypotheses. Journals and online articles are used for research purpose and also literature review to obtain the accurate information. 


\section{1) Macrothink}

\section{Sample/Data}

For understanding purpose, data is collected by a sample of 200 people both from upper and lower level employee. Questionnaires were distributed between different age group of people. 34 questionnaires were rejected due to missing data. Remaining 166 are selected. The response rate for current study is $80 \%$ that is quite good.

A non-probability sampling technique is used in current study that is also known as convenience sampling. Convenience sampling is to get the related information from the sample that is available easily (Zikmund, 1991). It is most commonly used technique because it is the best way of getting effective information fastly.

\section{Instrument and measures}

The research is done through distribution of questionnaire. The survey instrument of the current study contains two main purposes. First is to examine the relation of different variables on turnover intention. Second is to collect information about the different characters like age, gender, income level and organization of the respondents to know about the variation of results.

The survey instrument contains two sections, A and B. Section A is about personal information of respondent. The objective of asking personal question was to get basic information about the respondents. Section B includes the questions about independent variables and dependent variable of current study. It comprises the factors such as job satisfaction, job performance, emotional intelligence, leader membership exchange and organizational commitment on turnover intention. The purpose is to judge the different aspects of turnover intention.

\section{Scale Measurement}

Table No.1

\begin{tabular}{|l|l|l|l|}
\hline No. & \multicolumn{1}{|l|}{ Variables } & Items & Reference \\
\hline 1 & $\begin{array}{l}\text { Turnover } \\
\text { intention }\end{array}$ & $\begin{array}{l}\text { 1. I often think about quitting. } \\
\text { 2. It is likely that I will actively look for a new job } \\
\text { next year. } \\
\text { 3. I will probably look for a new job in the next. } \\
\text { 4. I often think of changing my job. }\end{array}$ & $\begin{array}{l}\text { (Dress \& shaw, } \\
\text { 2001) }\end{array}$ \\
\hline
\end{tabular}




\begin{tabular}{|c|c|c|c|}
\hline 2 & $\begin{array}{l}\text { Job } \\
\text { Satisfaction }\end{array}$ & $\begin{array}{l}\text { 1. Overall, I am pleased with my work } \\
\text { 2. Overall, I am satisfied in my current } \\
\text { practice } \\
\text { 3. My work in this practice has met my } \\
\text { expectations } \\
\text { 4. My current work situation is not a major } \\
\text { source of frustration in my life. }\end{array}$ & $\begin{array}{l}\text { (Blau, } \\
1987 \\
\text { (Susskind et al., } \\
\text { 2000), }\end{array}$ \\
\hline 3 & $\begin{array}{l}\text { Job } \\
\text { performance }\end{array}$ & $\begin{array}{l}\text { 1. My performance is better than that of my } \\
\text { colleagues with similar qualifications. } \\
\text { 2. I am satisfied with my performance because } \\
\text { it is mostly good. } \\
\text { 3. My performance is better than that of } \\
\text { employees with similar qualifications in } \\
\text { other organizations. }\end{array}$ & (Vroom, 1964), \\
\hline 4 & $\begin{array}{l}\text { Leader } \\
\text { membership } \\
\text { exchange }\end{array}$ & $\begin{array}{l}\text { 1. I like my supervisor very much as a person. } \\
\text { 2. I admire my supervisor's professional skills. } \\
\text { 3. I do not mind working my hardest for my } \\
\text { supervisor. } \\
\text { 4. My supervisor would defend me to others in } \\
\text { the organization if I made an honest mistake }\end{array}$ & $\begin{array}{l}\text { Dansereau et } \\
\text { al.'s (1975), } \\
\text { Graen et al., } \\
\text { 1982). }\end{array}$ \\
\hline 5 & $\begin{array}{l}\text { Emotional } \\
\text { intelligence }\end{array}$ & $\begin{array}{l}\text { 1. I can explain the emotions I feel to team } \\
\text { member. } \\
\text { 2. When I am frustrated with fellow team } \\
\text { members, I can overcome my frustration. } \\
\text { 3. I can read fellow team members 'true' } \\
\text { feelings even if they try to hide them. } \\
\text { 4. I can able to cheer team member up when } \\
\text { they are feeling down. }\end{array}$ & $\begin{array}{l}\text { Mayer \& } \\
\text { Salovey (1997), } \\
\text { (Ashkanasy and } \\
\text { Daus, 2005) }\end{array}$ \\
\hline
\end{tabular}




\begin{tabular}{|c|c|c|}
\hline $\begin{array}{l}\text { Organizational } \\
\text { commitment }\end{array}$ & $\begin{array}{l}\text { 1. I would accept almost any type of job } \\
\text { assignment in order to keep working for this } \\
\text { organization. } \\
\text { 2. I feel very little loyalty to this organization. } \\
\text { 3. I am proud to tell others that I am part of } \\
\text { this organization. } \\
\text { 4. I talk up this organization to my friends as a } \\
\text { great organization to work for. } \\
\text { 5. It would take very little chance in my } \\
\text { present circumstances to cause me to leave. }\end{array}$ & $\begin{array}{l}\text { Bartol,K.(1979). } \\
\text { (Mathieu and } \\
\text { Zajac, 1990). }\end{array}$ \\
\hline
\end{tabular}

\section{Procedure}

200 questionnaires were distributed and respondents are selected on the criteria above mentioned. Before giving the questionnaire, the objective of study and questions were explained to the respondents so they can easily fill the questionnaire. A total of 166 questionnaires were selected and rest of questionnaires was not included in the further analysis due to incomplete and invalid responses. After collecting the completed questionnaires, these questionnaires were coded and entered into SPSS sheet for further analysis.

\section{Reliability analysis}

To check the reliability of different variables, we use Cronbach Alpha. The acceptable values are 0.5 by Nunnally (1970) and 0.6 by Moss et al. (1998)

Table No.2

\begin{tabular}{|l|l|l|}
\hline Scales & Items & $\begin{array}{l}\text { Cronbach } \\
\text { Alpha }\end{array}$ \\
\hline Turnover intentions & 4 & .891 \\
Job satisfaction & 4 & .813 \\
Job performance & 3 & .742 \\
Leader membership exchange & 4 & .846 \\
Emotional intelligence & 4 & .703 \\
Organizational Commitment & 5 & .583 \\
\hline
\end{tabular}




\section{Result and Analysis}

Profile of the respondents: Demographic information such as age, gender, income level and organization is represented by the following table.

\begin{tabular}{|l|l|l|l|}
\hline Variables & Category & Frequency & Percentage \\
\hline Gender & Male & 78 & 47 \\
& Female & 88 & 53 \\
\hline Age & Below 20 & 20 & 12 \\
& $20-30$ & 98 & 59 \\
& $30-40$ & 26 & 15.7 \\
Above 40 & 22 & 13.3 \\
\hline Income level & Below 10000 & 47 & 28.3 \\
& $10000-20000$ & 45 & 27.1 \\
& 20000-30000 & 41 & 24.7 \\
& Above 30000 & 33 & 19.9 \\
\hline
\end{tabular}

\section{Hypothesis testing}

\section{Job Satisfaction and Turnover intention}

According to the current study, job satisfaction and turnover intention have a negative relationship that is significant with $(\beta=-.422),(p=0.000)$. These results confirm H1.

\section{Job performance and Turnover Intention}

The regression results confirm the significant negative relationship between turnover intention and job performance. $(\beta=-.141),(\mathrm{p}=.042)$. According to results, job performance contributes more than $14 \%$ to turnover intention. These results confirm $\mathrm{H} 2$.

\section{Leader membership exchange (LMX) and turnover intention}

Analysis shows that turnover intention and LMX have significant negative relationship with $(\beta=-.206),(p=0.018)$.It validates $H 3$. 


\section{Macrothink \\ International Journal of Learning \& Development \\ ISSN 2164-4063 \\ 2014, Vol. 4, No. 2}

\section{Emotional intelligence and turnover intentions}

As considering the significance between turnover intention and emotional intelligence, the results of current study shows no significant negative relationship between these two variables with $(\beta=.150),(p=0.047)$.It rejects $H 4$.

\section{Organizational commitment and turnover intention}

Current results shows that there is no negative relationship between turnover intention and organizational commitment with $(\beta=.080),(\mathrm{p}=.360)$. Based on these results, H5 is rejected.

There is $23 \%$ variation in turnover intention due to job satisfaction, job performance, LMX, emotional intelligence and organizational commitment.

\begin{tabular}{|c|c|c|c|c|c|c|}
\hline Hypothesis & Model variables & Estimate & S.E & C.R & $\mathrm{P}$ & Results \\
\hline $\mathrm{H} 1$ & $\begin{array}{l}\text { Turnover } \leftarrow \text { job } \\
\text { sat_ } \\
\text { intention }\end{array}$ & -.422 & .106 & -4.747 & .000 & supported \\
\hline $\mathrm{H} 2$ & $\begin{array}{l}\text { Turnover } \longleftarrow \\
\text { perfor_ } \\
\text { intention }\end{array}$ & -.141 & .120 & -2.048 & .042 & supported \\
\hline $\mathrm{H} 3$ & $\begin{array}{l}\text { Turnover } \leftarrow \\
\text { LMX } \\
\text { Intention }\end{array}$ & -.206 & .103 & -2.395 & 0.018 & supported \\
\hline H4 & $\begin{array}{l}\text { Turnover } \leftarrow \quad \text { Emotional } \\
\text { int_- } \\
\text { Intention }\end{array}$ & .150 & .116 & 2.002 & .047 & Not supported \\
\hline H5 & $\begin{array}{l}\text { Turnover } \leftarrow \\
\text { Commit_- } \\
\text { Intention }\end{array}$ & .080 & .135 & .918 & .360 & Not supported \\
\hline
\end{tabular}




\section{Research Model}

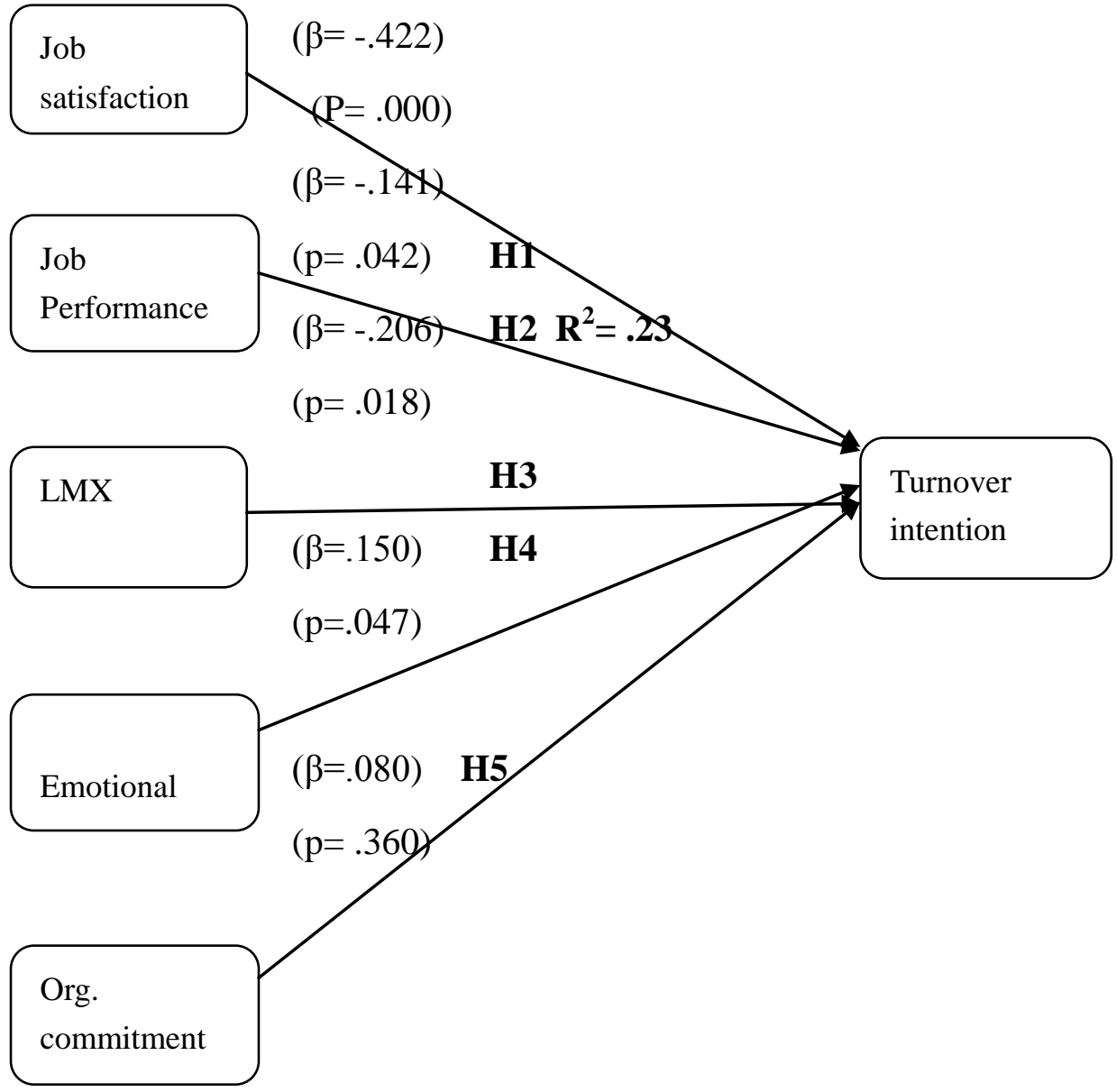

\section{Discussion and conclusion}

The objective of our research was to find the effect of independent variables (organizational commitment, emotional intelligence, job satisfaction leader membership exchange and job performance) on the dependent variable (turnover intention). The objective of this study was also to check the research model. We used linear regression analysis to find the impact of independent variables on dependent variable. The research of (Ramesh Kumar, Charles Ramendran \&Peter Yacob, 2012) proved that there is a significant relationship between organizational commitment and turnover intention as the p-value of their research was 0.000 which is less than alpha value 0.01 but our study showed the insignificant effect of organizational commitment on turnover intention. The reason of rejection of this hypothesis is the poor response of the respondent and biasness of the respondent and organizational commitment is not only responsible for low turnover intention. In current economic conditions everyone wants to get the best so if one comes with best opportunities and required working conditions then organizational commitment no more plays role in decreasing turnover intention.

The study of (Peter J. Jordan\& Ashlea Troth, 2010) proved the negative impact of emotional intelligence and turnover intention. Emotional intelligence refers to the awareness 
and management of own emotions as well as others emotions. Higher quality relationships are formed by the employee with higher emotional intelligence but relationships are not the only to lower turnover intention. our research rejected this hypothesis because there is significant positive effect of emotional intelligence on turnover intention. This hypothesis was rejected because mostly people hide their true feeling that is why they did not give fair response.

We proved by linear regression analysis that the relationship of job performance on turnover intention is significantly negative. If the job performance is better, the employee will not leave the organization because he becomes satisfy with his work. If job performance of the employee is not better it will increase the intention of employees to leave the organization and dissatisfaction decreases. Higher performance leads toward benefits and rewards and retain the entity of employees greater than the low job performance that can become a cause of turnover.

Our study proved the negative relationship between the job satisfaction and turnover intention. When the job satisfaction is greater the turnover intention will be lesser and vice versa. Job performance is an individual's ability to perform certain tasks. Employees feeling of pleasure with his/her job is job satisfaction. Job satisfaction is the difference between the employees expected benefit and the benefit which he/she actually receive. Higher the difference between expected benefits and actual benefits will result in higher turnover intention. The organizations should work to minimize this difference to make their employees more satisfied to reduce their turnover intention. Our study is that when the employees are more satisfied they retain their entity but if they are not satisfied they leave the organization.

There is a significant negative relationship between leader membership exchange and the turnover intention. If the flow of information between leader and members are more fluent they will be more satisfied with their job and their intention of turnover will be lower. High information exchange between leader and follower generates loyal relations and the employees with effective relationships with seniors are also treated on preferential basis. The organizations should work to increase relationship between the leader and members so that they may understand each other and the result in lower turnover intention of employees. If the relationship between leader and members is poor the employee's turnover intention will be motivated.

\section{Limitation and future research}

The limitation of our study is that it only covers the response of employees of Bahawalpur. Current market trends in Bahawalpur are may be different from the trends of other cities and this result in change intentions of employees. Sample size of our study is 200.sample size is small covering a limited area and limited influences of current situations. Major respondents of our study are females and turnover intention of females varies from turnover intention of males as our society is concerned. Results will be different if respondents will be from different cities and countries because intentions vary from society to society and economy to economy. 


\section{References}

Allen, D.G. and Griffeth, R.W. (1999), "Job performance and turnover: a review and integrative multi-route model”, Human Resource Management Review, Vol. 9, pp. 525-48.

Ashkanasy, N.M. and Daus, C.S. (2005), "Rumors of the death of emotional intelligence in organizational behavior are vastly exaggerated", Journal of Organizational Behavior, Vol. 26, pp. 441-52.

Blau, G.J. (1987), "Locus of control as a potential moderator of the turnover process", Journal of Occupational Psychology, Vol. 60 No. 1, pp. 21-9.

Brayfield, A.H. and Crockett, W.H. (1955), "Employee attitudes and employee performance”, Psychological Bulletin, Vol. 52, pp. 396-424.

Birnbaum, D. and Somers, M.J. (1993), "Fitting job performance into turnover model: an examination of the form of the job performance-turnover relationship and a path model", Journal of Management, Vol. 19, pp. 1-11.

Bartol,K.(1979). Professionalism as a predict of organizational commitment, roles stress and turnover: A multidimensional approach. Academy of Management Journal, 22(4), 815-822.

Blau, G. J. (1987). Conceptualizing How Job Involvement and Organizational Commitment Affect Turnover and Absenteeism. Academy of Management Review, 12(2), 288-300.

Bauer et al,2006: Gerstner and day, 1997: Schyns et al 2007).(Schyns, B. and Wolfram, H.-J. (2008), "The relationship between leader-member exchange and outcomes as rated by leaders and followers", Leadership and Organization Development Journal, Vol. 29, pp. 631-46

Dress, G.G and J.D .Shaw, 2001 . Voluntary turnover, Social capital and Organizational performance. Acad Manage. Rev.,26: 446-456

*Dansereauet al.'s (1975) ,..LMX(Dansereau, F.J., Graen, G. and Haga, W.J. (1975), “A vertical dyad linkage approach to leadership within formal organizations: a longitudinal investigation of the role-making process", Organizational Behavior and Human Performance, Vol. 13, pp. 46-78.

Grobler, P., S warnich, 2005. Human resource Management in South Africa, $3^{\text {rd }}$ Edn., Thomson Learning., London pp: 20-32

Graen, G.B., Novak, M.A. and Sommerkamp, P. (1982), “The effects of leader-member exchange and job design on productivity and job satisfaction: testing a dual attachment model”, Organizational Behavior and Human Performance, Vol. 30, pp. 109-31.)

Jordan et al. (2002),(Jordan, P.J., Ashkanasy, N.M., Ha“rtel, C.E.J. and Hooper, G.S. (2002), "Workgroup emotional intelligence: scale development and relationship to team process effectiveness and goal focus", Human Resource Management Review, Vol. 12, pp. 195-214.) 


\section{I Macrothink}

International Journal of Learning \& Development

ISSN 2164-4063

2014, Vol. 4, No. 2

Jeffrey Pfeffer (2007) Human Resources from an Organizational Behavior Perspective: Some Paradoxes Explained The Journal of Economic Perspectives Vol. 21, No. 4. pp. 115134

Lee, R.T. and Ashforth, B.E. (1993), "A further examination of managerial burnout: toward an integrated model", Journal of Organizational Behavior, Vol. 14 No. 1, pp. 3-20

Mathieu, J.E. and Zajac, D.M. (1990), "A review and meta-analysis of the antecedents, correlates, and consequences of organizational commitment", Psychological Bulletin, Vol. 108 No. 2, pp. 171-94.

Mobley, W.H. (1977), "Intermediate linkages in the relationship between job satisfaction and employee turnover", Journal of Applied Psychology, Vol. 62, pp. 237-40.

Mitchell, T.R., Holtom, B.C., Lee, T.W., Sablynski, C.J. and Erez, M. (2001), "Why people stay: using job embeddedness to predict voluntary turnover", Academy of Management Journal,Vol. 44, pp. 1102-21.

Meyer, J.P and N.J Allen, 1991. A three-component conceptualization of organizational commitment. Hum. Resour. Manage. Rev., 1:61-89

Mayer and Salovey (1997)(Mayer, J.D. and Salovey, P. (1997), "What is emotional intelligence?", in Salovey, P. and

Sluyter, D.J. (Eds), Emotional Development and Emotional Intelligence: Educational Implications, Basic Books, New York, NY, pp. 3-31.)

Reily, D. 2006. Turnover intention. The mediation effect of job satisfaction, affective commitment and continuance commitment. Master thesis, University of Waikato.

Spector, P.E. (1982), "Behavior in organizations as a function of employees' locus of control",Psychological Bulletin, Vol. 3, pp. 482-97.

Staw, B. M. (1980). The consequences of turnover. Journal of Occupational Behavior . 1, 253-273.

Salovey (1997)... Emotional intelligence (Salovey, P. and Grewal, D. (2005), "The science of emotional intelligence", Current Directions in Psychological Science, Vol. 14, pp. 281-5.)

Susskind, A.M., Borchgrevink, C.P., Kacmar, K.M. and Brymer, R.A. (2000), "Customer service Employees' behavioral intentions and attitudes: an examination of construct validity and a path model", International Journal of Hospitality Management, Vol. 19 No. 1, pp. 53-77.

Testa, M.R. (2001), "Organizational commitment, job satisfaction, and effort in the service environment”, The Journal of Psychology, Vol. 135 No. 2, pp. 226-36.

Vroom, V.H. (1964), Work and Motivation, Wiley, New York, NY. 